\title{
Medical Therapy for Pediatric Pulmonary Arterial Hypertension
}

\author{
Cecile Tissot, MD, David Dunbar Ivy, MD, and Maurice Beghetti, MD \\ Pediatric Cardiology Unit, The Children's University Hospital of Geneva, Geneva, Switzerland \\ (C.T., M.B.); and The Children's Hospital Heart Institute, The Children's Hospital, University of \\ Colorado Denver School of Medicine, Aurora, CO (C.T., D.I.)
}

\begin{abstract}
Pulmonary arterial hypertension (PAH) is a life-threatening disease, the prognosis of which has changed dramatically in the past decade since the introduction of new therapeutic agents and the off-label application of adult pulmonary hypertension $(\mathrm{PH})$-specific therapies to children. ${ }^{1-3}$ However, PAH still has no cure, and the aim of treatment is to prolong survival by improving quality of life, symptoms, exercise capacity, and hemodynamics. The selection of appropriate therapies for pulmonary hypertension is complex, and they must be carefully chosen according to the etiology and pulmonary vasoreactivity. ${ }^{3}$ As insight advances into mechanisms responsible for the development of $\mathrm{PAH}$, we hope the introduction of novel therapeutic agents will further improve the outcome of this disease.
\end{abstract}

\section{Diagnosis and Classification}

PAH is defined hemodynamically as a mean pulmonary artery pressure (PAP) $\geq 25 \mathrm{~mm} \mathrm{Hg}$ at rest, with a pulmonary capillary wedge pressure within reference range $(\leq 15 \mathrm{~mm} \mathrm{Hg})$. Some definitions have also included the pulmonary vascular resistance, requiring the pulmonary vascular resistance index to be $\geq 3$ Woods units $\mathrm{x} \mathrm{m}{ }^{2} .{ }^{4}$ A revision of the classification including most of the forms of $\mathrm{PH}$ was proposed in Dana Point in 2008. ${ }^{5}$ The clinical presentation of children with PH has been reviewed; this outlines the difficulties of classifying pediatric $\mathrm{PH}$ according to this classification. ${ }^{6}$ The exact incidence and prevalence of $\mathrm{PH}$ in children is not known. In the French registry, the estimated prevalence for PAH in children was 3.7 cases/million. Patients had idiopathic PAH (60\%), familial PAH (10\%), PAH associated with congenital heart disease (24\%), PAH associated with connective tissue disease $(4 \%)$ or portal hypertension $(2 \%),{ }^{7}$ with similar results in other registries ${ }^{8-10}$ Those patients with a small congenital heart defect and severe idiopathic PAH remain difficult to classify. ${ }^{11} \mathrm{PH}$ associated with chronic lung disease ${ }^{12}$ or with sickle cell disease ${ }^{13}$ is probably underreported in the pediatric population.

\section{Clinical Presentation and Diagnostic Evaluation}

Symptoms of PAH in children are frequently misleading, and the diagnosis may be unrecognized for some time. A high degree of suspicion should be the rule, and PAH should be suspected in any child with undue shortness of breath, tiredness, or syncopal episodes. ${ }^{10}$ Although associated PAH is rare in children, except for PH related to congenital heart disease, all potential etiologies should be evaluated. ${ }^{10} \mathrm{PAH}$ must be confirmed with catheterization, and pulmonary vasoreactivity testing should be performed, usually with inhaled nitric oxide (NO). ${ }^{14}$ It is uncertain whether the same definition of vasoreactivity

Copyright @ 2010 Mosby Inc. All rights reserved.

Reprint requests: D. Dunbar Ivy, MD, Professor of Pediatrics, Section Head, Cardiology, Selby's Chair in Pediatric Cardiology, Director, Pulmonary Hypertension Program, The Children's Hospital, 13123 East 16th Ave, B-100, Aurora, CO 80045. ivy.dunbar@tchden.org.

C.T. has no conflicts of interest to disclose. 
should be applied for adults and children (decrease $\geq 10 \mathrm{~mm} \mathrm{Hg}$ in the mean PAP with a mean PAP $\leq 40 \mathrm{~mm} \mathrm{Hg}$ and an unchanged or increased cardiac output).

\section{Therapeutic Approach}

There are no evidence-based treatment recommendations for children with PAH, primarily because of the lack of results from randomized clinical trials in pediatric patients or including pediatric patients. ${ }^{3,15}$ The aim of medical treatment is to dilate and reverse the abnormal remodeling of the pulmonary vascular bed and to restore endothelial function, by acting on the prostacyclin, endothelin, and NO pathways. In practice, a therapeutic algorithm similar to PAH in adults appears to guide treatment of children with PAH (Figure). ${ }^{3,15,16}$ However, there are some difficulties in applying adult criteria and dosage regimens to children. Acute responders with PAH associated with congenital shunt lesions are considered candidates for surgical repair. ${ }^{11}$ In responders to acute vasodilator testing in repaired congenital heart disease or idiopathic PAH, calcium channel blockers may be considered. In the "non-responder" with right heart failure, the first line of treatment consists of continuous intravenous prostacyclin, whereas in the absence of right heart failure, other targeted therapies (endothelin receptor antagonists, phosphodiesterase 5 inhibitors, or prostacyclin analogues) may be tried first. Non-responders have a very limited survival rate when not treated with targeted therapies. ${ }^{2,17}$ Treatment for patients with congenital left-to-right shunts and irreversible PAH (Eisenmengers syndrome) is based on the same selective regimen as in idiopathic PAH, even when data are limited. ${ }^{18}$

Calcium channel blockers are used infrequently as first-line therapy in children. Chronic calcium channel blockade is efficacious in patients who demonstrate an acute response to vasodilator testing. Approximately $7 \%$ to $40 \%$ of children with chronic PAH are "responders" and can be effectively treated with oral calcium channel blockers. ${ }^{2,9}$ In children with idiopathic PAH, Barst et al showed that 5-year survival rates improved significantly in acute vasoreactive responders treated with calcium channel blockers compared with non-responders. ${ }^{2}$ Careful follow-up is essential because patients treated with calcium channel blockers may deteriorate with time. ${ }^{19}$

Prostacyclin is a metabolite of arachidonic acid endogenously produced by the vascular endothelium. It is a potent pulmonary and systemic vasodilator with anti-platelet activity. Children with severe PAH show diminished prostacyclin synthase expression in the lung vasculature.

Epoprostenol is a synthetic prostacyclin used via intravenous infusion, and has been shown to improve hemodynamics, quality of life, exercise capacity, and survival rate in adults and children with idiopathic PAH and APAH. ${ }^{2,19}$ Epoprostenol is known to lower PAP, increase cardiac output and increase oxygen transport. Barst et al have shown improved survival rate in children treated with long-term intravenous epoprostenol, with a 4-year survival rate for treated children of $94 \%$, compared with $38 \%$ in untreated patients, ${ }^{2}$ and Yung et al have reported a 10-year treatment success rate (freedom from death, transplantation, or atrioseptostomy) of $37 \% .{ }^{19}$ The development of tolerance or tachyphylaxis is possible, and most children need periodic dose escalation. Diarrhea, jaw pain, bone pain, systemic vasodilation, and thromboembolic events related to catheter delivery are known adverse effects. Epoprostenol has a short half-life (1-2 minutes), rendering a continuous intravenous infusion with a permanent central venous catheter necessary. Complications such as line sepsis, local infection, and catheter dislodgement are not unusual. ${ }^{20}$

Iloprost is an inhaled prostacyclin analogue with a longer half-life of 20 to 30 minutes. A recent review summarizes its use in pediatric $\mathrm{PAH} .{ }^{21}$ In children treated with iloprost, World Health Organization (WHO) functional class has been shown to be improved in 35\%, 
remained unchanged in 50\%, and decreased in $15 \% .{ }^{22}$ Lower-airway reactivity is a problem in some children, as is poor compliance with the need for frequent aerosol administrations (6-8 times daily). In the critical care setting of congenital heart defects, inhaled iloprost has been shown to be as efficacious as NO in lowering mean pulmonary vascular resistance and improve systemic oxygen saturation. ${ }^{23}$

Treprostinil is a prostacyclin analogue usually administered with continuous subcutaneous infusion and also is approved by the US Food and Drug Administration (FDA) for intravenous and inhaled delivery. Subcutaneous treprostinil has been shown to improve exercise tolerance, clinical signs, symptoms, and hemodynamics in adult patients with $\mathrm{PAH},{ }^{24}$ but discomfort at the infusion site is common and represents the most limiting factor in children. The use of intravenous treprostinil in children can be considered for patients who have been on a stable dose of intravenous epoprostenol with clinical improvement. ${ }^{25}$ Treprostinil has been studied in an inhaled form in adults ${ }^{26}$ and was recently approved by the FDA but there are no data in children.

Endothelin-1 (ET-1) is a potent vasoactive peptide produced primarily in the vascular endothelial cell, but also may be produced by smooth muscle cells. Two receptor sub-types, $\mathrm{ET}_{\mathrm{A}}$ and $\mathrm{ET}_{\mathrm{B}}$, mediate the activity of $\mathrm{ET}-1 . \mathrm{ET}_{\mathrm{A}}$ and $\mathrm{ET}_{\mathrm{B}}$ receptors on vascular smooth muscle mediate vasoconstriction, whereas $\mathrm{ET}_{\mathrm{B}}$ receptors on endothelial cells cause release of $\mathrm{NO}$ and prostacyclin and act as clearance receptors for circulating ET-1. ${ }^{27}$

Bosentan is an oral dual endothelin receptor antagonist ${ }^{28}$ acting on both $\mathrm{ET}_{\mathrm{A}}$ and $\mathrm{ET}_{\mathrm{B}}$ receptors. A recent review summarizes its use in pediatric $\mathrm{PAH} .{ }^{29}$ In recent uncontrolled studies in children with PAH, bosentan has been shown to lower mean PAP and PVR ${ }^{30}$ and improve WHO functional status and survival estimates at 1 and 2 years (98\% and 91\%, respectively). ${ }^{31}$ However, in a study including both children and adults with PAH and systemic-to-pulmonary shunt, bosentan therapy has been shown to produce only short-term improvement in WHO functional class and 6-minute walk distance. ${ }^{32}$ There was a progressive decline in the beneficial effect of bosentan after 1 year, with a more pronounced decline in the children, who tended to have more severe disease at baseline. ${ }^{32}$ Common adverse effects include dose-related hepatotoxicity, teratogenicity, and possibly male infertility; ${ }^{8}$ liver function tests should be performed monthly. The safety of bosentan therapy in children with PAH has been recently reported by Beghetti et al. ${ }^{8}$ Elevated transaminase levels were reported in $2.7 \%$ of children, compared with $7.8 \%$ of patients aged $\geq 12$ years, and the overall discontinuation rate from bosentan was $14 \%$ in children, compared with $28 \%$ in patients aged $\geq 12$ years, mainly related to death, hospitalization, or adverse events. Bosentan has been studied in Eisenmenger syndrome in a placebo-controlled trial in adult patients, the Breathe-5 study. Bosentan was well tolerated and improved exercise capacity and hemodynamics without compromising peripheral oxygen saturation. ${ }^{33}$ A specific pediatric formulation has been recently approved in Europe. ${ }^{34}$

Sitaxsentan and ambrisentan are oral selective $\mathrm{ET}_{\mathrm{A}}$ receptor antagonists with a long half life.$^{27}$ They block the vasoconstrictor effect of $\mathrm{ET}_{\mathrm{A}}$ receptors while maintaining the vasodilator effect and clearance function of $\mathrm{ET}_{\mathrm{B}}$ receptors. Sitaxsentan and ambrisentan have shown beneficial effects on exercise capacity and New York Heart Association functional class in adult patients, ${ }^{35,36}$ but little data are available for children. ${ }^{37}$

Phosphodiesterase type 5 inhibitors prevent the breakdown of cyclic guanosine monphosphate, resulting in pulmonary vasodilation. Phosphodiesterase type 5 inhibitors are acute pulmonary vasodilators as efficient as inhaled NO and potentiate pulmonary vasodilation with NO. They may be particularly beneficial in conjunction with NO, when withdrawal of NO may lead to rebound PAH. ${ }^{38,39}$ 
Sildenafil can be used orally, and recently the intravenous formulation has been approved by the FDA. Sildenafil has been approved for the treatment of WHO functional class II to IV PAH adult patients ${ }^{40}$ the data in children remain limited. In a pilot study of 14 children with PAH, oral sildenafil decreased PAP and PVR significantly and improved the mean 6-MWD, but a plateau was reached between 6 and 12 months. ${ }^{41}$ In a small study of children with idiopathic PAH and PH associated with congenital heart disease, sildenafil has been shown to improve oxyhemoglobin saturation and exercise capacity without significant adverse effects. ${ }^{42}$ In children with PAH associated with chronic lung disease, sildenafil has been shown to improve hemodynamics in $88 \%$ of patients, was well tolerated, and did not worsen oxyhemoglobin saturation. ${ }^{43}$ Moreover, phosphodiesterase type 5 appears to be highly expressed in the hypertrophied human right ventricle, and acute inhibition with oral sildenafil has been shown to improve right ventricular contractility. ${ }^{44}$ Adverse effects include headache, flushing, exacerbation of nosebleeds, and rare systemic hypotension or erections. A randomized placebo-controlled trial of oral sildenafil has been completed in pediatric patients, with the initial results presented in abstract form. ${ }^{45}$

Intravenous sildenafil has been shown to potentiate the increase in cyclic guanosine monophosphate in response to NO in children with increased PVR related to congenital heart disease or to postoperative state. However, sildenafil infusion was associated with increased intrapulmonary shunting and augmentation of hypoxemia related to V/Q mismatch in the postoperative patient with congenital heart disease. ${ }^{46,47}$ However, a recent study of intravenous sildenafil has shown improvement in oxygenation index in persistent pulmonary hypertension of the newborn in patients treated with or without inhaled NO. ${ }^{48}$

Tadalafil is also a selective phosphodiesterase type 5 inhibitor with a longer duration of action (half life, 17 hours). Tadalafil was recently approved by the FDA in 2009 for adults with PAH, but no data are available in children.

As for patients with right heart failure, combination therapy is an attractive option to address simultaneously the multiple pathophysiological pathways present in PAH. It is understandable that acting on the three different pathways of PAH may be more efficacious than acting on a single one, by additive or synergistic effects. ${ }^{49,50}$ Whether combination therapy should be used as a first step by simultaneous initiation of two or more drugs or by addition of a second treatment to an earlier therapy once insufficient is still not known; more studies are needed to help establishing guidelines. Even when empiric combinations of drugs is not uncommon in pediatric patients with PAH, there is a clear lack of studies in this area.

\section{Creation of a Right-to-Left Shunt and Transplantation}

Children not responding to conventional medical therapy may be candidates for atrioseptostomy or transplantation. Atrioseptostomy may benefit patients with severe PAH with recurrent syncope and intractable right heart failure unresponsive to medical therapy. Right-to-left shunting through an interatrial defect allows maintenance of cardiac output at the expense of increased hypoxemia and alleviates signs of right heart failure by decompression of the right heart. ${ }^{51}$ Transplantation should be reserved for children with PAH, which has progressed despite optimal medical therapy, and children should be listed for transplantation when their probability of 2-year survival without transplantation is $\leq 50 \% .52$

\section{Conclusion}

Advances in the understanding of pulmonary vasculature has led to new therapeutic options and improved survival rates in children with PAH. Timely diagnosis is crucial because earlier treatment leads to improved outcome. In children with PAH, an extensive work-up is 
necessary to determine the etiology, because the most successful strategy involves treatment of the underlying disorder. Initial evaluation includes acute vasodilator testing at cardiac catheterization, which determines initial therapy. Several novel therapeutic agents are under investigation, and evolving clinical research should better define the role of new medical treatments for children with PAH.

\section{Acknowledgments}

D.I. has served on scientific advisory boards for Actelion, Gilead, Pfizer, and United Therapeutics and has received research grant funding from Actelion and United Therapeutics. M.B. has served on advisory boards and consulted for Pfizer, Actelion Pharmaceuticals, Bayer Schering, GlaxoSmithKline, Novartis INO Therapeutics, Eli Lilly, and Mondobiotech, and has received lecture fees from Actelion Pharmaceuticals, Enycysive Pharmaceuticals, and Bayer Schering.

This research was funded both by Actelion and General Clinical Research Centers, National Center for Research Resources, National Institutes of Health (M01-RR0069).

\section{Glossary}

$\begin{array}{ll}\text { ET-1 } & \text { Endothelin-1 receptor antagonists } \\ \text { FDA } & \text { US Food and Drug Administration } \\ \text { NO } & \text { Nitric oxide } \\ \text { PAH } & \text { Pulmonary arterial hypertension } \\ \text { PAP } & \text { Pulmonary artery pressure } \\ \text { PH } & \text { Pulmonary hypertension } \\ \text { WHO } & \text { World Health Organization }\end{array}$

\section{References}

1. McLaughlin VV, Archer SL, Badesch DB, Barst RJ, Farber HW, Lindner JR, et al. ACCF/AHA 2009 expert consensus document on pulmonary hypertension: a report of the American College of Cardiology Foundation Task Force on Expert Consensus Documents and the American Heart Association: developed in collaboration with the American College of Chest Physicians, American Thoracic Society, Inc. and the Pulmonary Hypertension Association. Circulation. 2009; 119:225094. [PubMed: 19332472]

2. Barst RJ, Maislin G, Fishman AP. Vasodilator therapy for primary pulmonary hypertension in children. Circulation. 1999; 99:1197-208. [PubMed: 10069788]

3. Ivy DD, Feinstein JA, Humpl T, Rosenzweig EB. Non-congenital heart disease associated pediatric pulmonary arterial hypertension. Prog Pediatr Cardiol. 2009; 27:13-23.

4. Badesch DB, Champion HC, Sanchez MA, Hoeper MM, Loyd JE, Manes A, et al. Diagnosis and assessment of pulmonary arterial hypertension. J Am Coll Cardiol. 2009; 54(1 Suppl):S55-66. [PubMed: 19555859]

5. Simonneau G, Robbins IM, Beghetti M, Channick RN, Delcroix M, Denton CP, et al. Updated clinical classification of pulmonary hypertension. J Am Coll Cardiol. 2009; 54(1 Suppl):S43-54. [PubMed: 19555858]

6. van Loon RL, Roofthooft MT, van Osch-Gevers M, Delhaas T, Strengers JL, Blom NA, et al. Clinical characterization of pediatric pulmonary hypertension: complex presentation and diagnosis. J Pediatr. 2009; 155:176-82. e1. [PubMed: 19524254]

7. Fraisse A, Jais X, Schleich JM, di Filippo S, Maragnes P, Beghetti M, et al. Characteristics and prospective 2-year follow-up of children with pulmonary arterial hypertension in France. Arch Cardiovasc Dis. 2010; 103:66-74. [PubMed: 20226425] 
8. Beghetti M, Hoeper MM, Kiely DG, Carlsen J, Schwierin B, Segal ES, et al. Safety experience with bosentan in 146 children 2-11 years old with pulmonary arterial hypertension: results from the European Post-marketing Surveillance program. Pediatr Res. 2008; 64:200-4. [PubMed: 18414142]

9. Haworth SG, Hislop AA. Treatment and survival in children with pulmonary arterial hypertension: the UK Pulmonary Hypertension Service for Children 2001-2006. Heart. 2009; 95:312-7. [PubMed: 18952635]

10. Rosenzweig EB, Feinstein JA, Humpl T, Ivy DD. Pulmonary arterial hypertension in children: diagnostic work up and challenges. Prog Pediat Cardiol. 2009; 27:7-11.

11. Kulik T, Mullen M, Adatia I. Pulmonary arterial hypertension associated with congenital heart disease. Prog Pediatr Cardiol. 2009; 27:25-33.

12. Mourani PM, Mullen M, Abman SH. Pulmonary hypertension in bronchopulmonary dysplasia. Prog Pediatr Cardiol. 2009; 27:43-8.

13. Nelson SC, Adade BB, McDonough EA, Moquist KL, Hennessy JM. High prevalence of pulmonary hypertension in children with sickle cell disease. J Pediatr Hematol Oncol. 2007; 29:334-7. [PubMed: 17483714]

14. Berner M, Beghetti M, Spahr-Schopfer I, Oberhansli I, Friedli B. Inhaled nitric oxide to test the vasodilator capacity of the pulmonary vascular bed in children with long-standing pulmonary hypertension and congenital heart disease. Am J Cardiol. 1996; 77:532-5. [PubMed: 8629600]

15. Galie N, Hoeper MM, Humbert M, Torbicki A, Vachiery JL, Barbera JA, et al. Guidelines for the diagnosis and treatment of pulmonary hypertension: The Task Force for the Diagnosis and Treatment of Pulmonary Hypertension of the European Society of Cardiology (ESC) and the European Respiratory Society (ERS), endorsed by the International Society of Heart and Lung Transplantation (ISHLT). Eur Heart J. 2009; 30:2493-537. [PubMed: 19713419]

16. Barst RJ, Gibbs JS, Ghofrani HA, Hoeper MM, McLaughlin VV, Rubin LJ, et al. Updated evidence-based treatment algorithm in pulmonary arterial hypertension. J Am Coll Cardiol. 2009; 54(1 Suppl):S78-84. [PubMed: 19555861]

17. Sandoval J, Bauerle O, Gomez A, Palomar A, Martinez Guerra ML, Furuya ME. Primary pulmonary hypertension in children: clinical characterization and survival. J Am Coll Cardiol. 1995; 25:466-74. [PubMed: 7829802]

18. Beghetti M, Galie N. Eisenmenger syndrome a clinical perspective in a new therapeutic era of pulmonary arterial hypertension. J Am Coll Cardiol. 2009; 53:733-40. [PubMed: 19245962]

19. Yung D, Widlitz AC, Rosenzweig EB, Kerstein D, Maislin G, Barst RJ. Outcomes in children with idiopathic pulmonary arterial hypertension. Circulation. 2004; 110:660-5. [PubMed: 15289375]

20. Ivy DD, Calderbank M, Wagner BD, Dolan S, Nyquist AC, Wade M, et al. Closed-hub systems with protected connections and the reduction of risk of catheter-related bloodstream infection in pediatric patients receiving intravenous prostanoid therapy for pulmonary hypertension. Infect Control Hosp Epidemiol. 2009; 30:823-9. [PubMed: 19637961]

21. Tissot C, Beghetti M. Review of inhaled iloprost for the control of pulmonary artery hypertension in children. Vasc Health Risk Manag. 2009; 5:325-31. [PubMed: 19436672]

22. Ivy DD, Doran AK, Smith KJ, Mallory GB Jr, Beghetti M, Barst RJ, et al. Short- and long-term effects of inhaled iloprost therapy in children with pulmonary arterial hypertension. J Am Coll Cardiol. 2008; 51:161-9. [PubMed: 18191742]

23. Rimensberger PC, Spahr-Schopfer I, Berner M, Jaeggi E, Kalangos A, Friedli B, et al. Inhaled nitric oxide versus aerosolized iloprost in secondary pulmonary hypertension in children with congenital heart disease: vasodilator capacity and cellular mechanisms. Circulation. 2001; 103:544-8. [PubMed: 11157720]

24. Simonneau G, Barst RJ, Galie N, Naeije R, Rich S, Bourge RC, et al. Continuous subcutaneous infusion of treprostinil, a prostacyclin analogue, in patients with pulmonary arterial hypertension: a double-blind, randomized, placebo-controlled trial. Am J Respir Crit Care Med. 2002; 165:800-4. [PubMed: 11897647]

25. Ivy DD, Claussen L, Doran A. Transition of stable pediatric patients with pulmonary arterial hypertension from intravenous epoprostenol to intravenous treprostinil. Am J Cardiol. 2007; 99:696-8. [PubMed: 17317374] 
26. Channick RN, Olschewski H, Seeger W, Staub T, Voswinckel R, Rubin LJ. Safety and efficacy of inhaled treprostinil as add-on therapy to bosentan in pulmonary arterial hypertension. J Am Coll Cardiol. 2006; 48:1433-7. [PubMed: 17010807]

27. Abman SH. Role of endothelin receptor antagonists in the treatment of pulmonary arterial hypertension. Annu Rev Med. 2009; 60:13-23. [PubMed: 18764741]

28. Rubin LJ, Badesch DB, Barst RJ, Galie N, Black CM, Keogh A, et al. Bosentan therapy for pulmonary arterial hypertension. N Engl J Med. 2002; 346:896-903. [PubMed: 11907289]

29. Beghetti M. Bosentan in pediatric patients with pulmonary arterial hypertension. Curr Vasc Pharmacol. 2009; 7:225-33. [PubMed: 19356006]

30. Barst RJ, Ivy D, Dingemanse J, Widlitz A, Schmitt K, Doran A, et al. Pharmacokinetics, safety, and efficacy of bosentan in pediatric patients with pulmonary arterial hypertension. Clin Pharmacol Ther. 2003; 73:372-82. [PubMed: 12709727]

31. Rosenzweig EB, Ivy DD, Widlitz A, Doran A, Claussen LR, Yung D, et al. Effects of long-term bosentan in children with pulmonary arterial hypertension. J Am Coll Cardiol. 2005; 46:697-704. [PubMed: 16098438]

32. van Loon RL, Hoendermis ES, Duffels MG, Vonk-Noordegraaf A, Mulder BJ, Hillege HL, et al. Long-term effect of bosentan in adults versus children with pulmonary arterial hypertension associated with systemic-to-pulmonary shunt: does the beneficial effect persist? Am Heart J. 2007; 154:776-82. [PubMed: 17893008]

33. Galie N, Beghetti M, Gatzoulis MA, Granton J, Berger RM, Lauer A, et al. Bosentan therapy in patients with Eisenmenger syndrome: a multicenter, double-blind, randomized, placebo-controlled study. Circulation. 2006; 114:48-54. [PubMed: 16801459]

34. Beghetti M, Haworth SG, Bonnet D, Barst RJ, Acar P, Fraisse A, et al. Pharmacokinetic and clinical profile of a novel formulation of bosentan in children with pulmonary arterial hypertension: the FUTURE-1 study. Br J Clin Pharmacol. 2009; 68:948-55. [PubMed: 20002090]

35. Barst RJ. Sitaxsentan: a selective endothelin-A receptor antagonist, for the treatment of pulmonary arterial hypertension. Expert Opin Pharmacother. 2007; 8:95-109. [PubMed: 17163810]

36. Galie N, Olschewski H, Oudiz RJ, Torres F, Frost A, Ghofrani HA, et al. Ambrisentan for the treatment of pulmonary arterial hypertension: results of the ambrisentan in pulmonary arterial hypertension, randomized, double-blind, placebo-controlled, multicenter, efficacy (ARIES) study 1 and 2. Circulation. 2008; 117:3010-9. [PubMed: 18506008]

37. Barst RJ, Langleben D, Frost A, Horn EM, Oudiz R, Shapiro S, et al. Sitaxsentan therapy for pulmonary arterial hypertension. Am J Respir Crit Care Med. 2004; 169:441-7. [PubMed: 14630619]

38. Atz AM, Wessel DL. Sildenafil ameliorates effects of inhaled nitric oxide withdrawal. Anesthesiology. 1999; 91:307-10. [PubMed: 10422958]

39. Namachivayam P, Theilen U, Butt WW, Cooper SM, Penny DJ, Shekerdemian LS. Sildenafil prevents rebound pulmonary hypertension after withdrawal of nitric oxide in children. Am J Respir Crit Care Med. 2006; 174:1042-7. [PubMed: 16917115]

40. Galie N, Ghofrani HA, Torbicki A, Barst RJ, Rubin LJ, Badesch D, et al. Sildenafil citrate therapy for pulmonary arterial hypertension. N Engl J Med. 2005; 353:2148-57. [PubMed: 16291984]

41. Humpl T, Reyes JT, Holtby H, Stephens D, Adatia I. Beneficial effect of oral sildenafil therapy on childhood pulmonary arterial hypertension: twelve-month clinical trial of a single-drug, openlabel, pilot study. Circulation. 2005; 111:3274-80. [PubMed: 15956137]

42. Karatza AA, Bush A, Magee AG. Safety and efficacy of sildenafil therapy in children with pulmonary hypertension. Int J Cardiol. 2005; 100:267-73. [PubMed: 15823634]

43. Mourani PM, Sontag MK, Ivy DD, Abman SH. Effects of long-term sildenafil treatment for pulmonary hypertension in infants with chronic lung disease. J Pediatr. 2009; 154:379-84. [PubMed: 18950791]

44. Nagendran J, Archer SL, Soliman D, Gurtu V, Moudgil R, Haromy A, et al. Phosphodiesterase type 5 is highly expressed in the hypertrophied human right ventricle, and acute inhibition of phosphodiesterase type 5 improves contractility. Circulation. 2007; 116:238-48. [PubMed: 17606845] 
45. Barst RJ, Richardson H, Konourina I, Group S. Oral sildenafil treatment in children with pulmonary arterial hypertension( $\mathrm{PAH})$ : results of a double-blind, placebo-controlled, dose-ranging study. European Respiratory Journal. 2009; 34(suppl 53):S3-4.

46. Schulze-Neick I, Hartenstein P, Li J, Stiller B, Nagdyman N, Hubler M, et al. Intravenous sildenafil is a potent pulmonary vasodilator in children with congenital heart disease. Circulation. 2003; 108(Suppl 1):II167-73. [PubMed: 12970227]

47. Stocker C, Penny DJ, Brizard CP, Cochrane AD, Soto R, Shekerdemian LS. Intravenous sildenafil and inhaled nitric oxide: a randomised trial in infants after cardiac surgery. Intensive Care Med. 2003; 29:1996-2003. [PubMed: 14530859]

48. Steinhorn RH, Kinsella JP, Pierce C, Butrous G, Dilleen M, Oakes M, et al. Intravenous sildenafil in the treatment of neonates with persistent pulmonary hypertension. J Pediatr. 2009; 155:841-7. [PubMed: 19836028]

49. Simonneau G, Rubin LJ, Galie N, Barst RJ, Fleming TR, Frost AE, et al. Addition of sildenafil to long-term intravenous epoprostenol therapy in patients with pulmonary arterial hypertension: a randomized trial. Ann Intern Med. 2008; 149:521-30. [PubMed: 18936500]

50. Ivy DD, Doran A, Claussen L, Bingaman D, Yetman A. Weaning and discontinuation of epoprostenol in children with idiopathic pulmonary arterial hypertension receiving concomitant bosentan. Am J Cardiol. 2004; 93:943-6. [PubMed: 15050507]

51. Micheletti A, Hislop AA, Lammers A, Bonhoeffer P, Derrick G, Rees P, et al. Role of atrial septostomy in the treatment of children with pulmonary arterial hypertension. Heart. 2006; 92:969-72. [PubMed: 16278272]

52. Hanna B, Conrad C. Lung transplantation for pediatric pulmonary hypertension. Progress in Pediatric Cardiology. 2009; 27:49-55. 


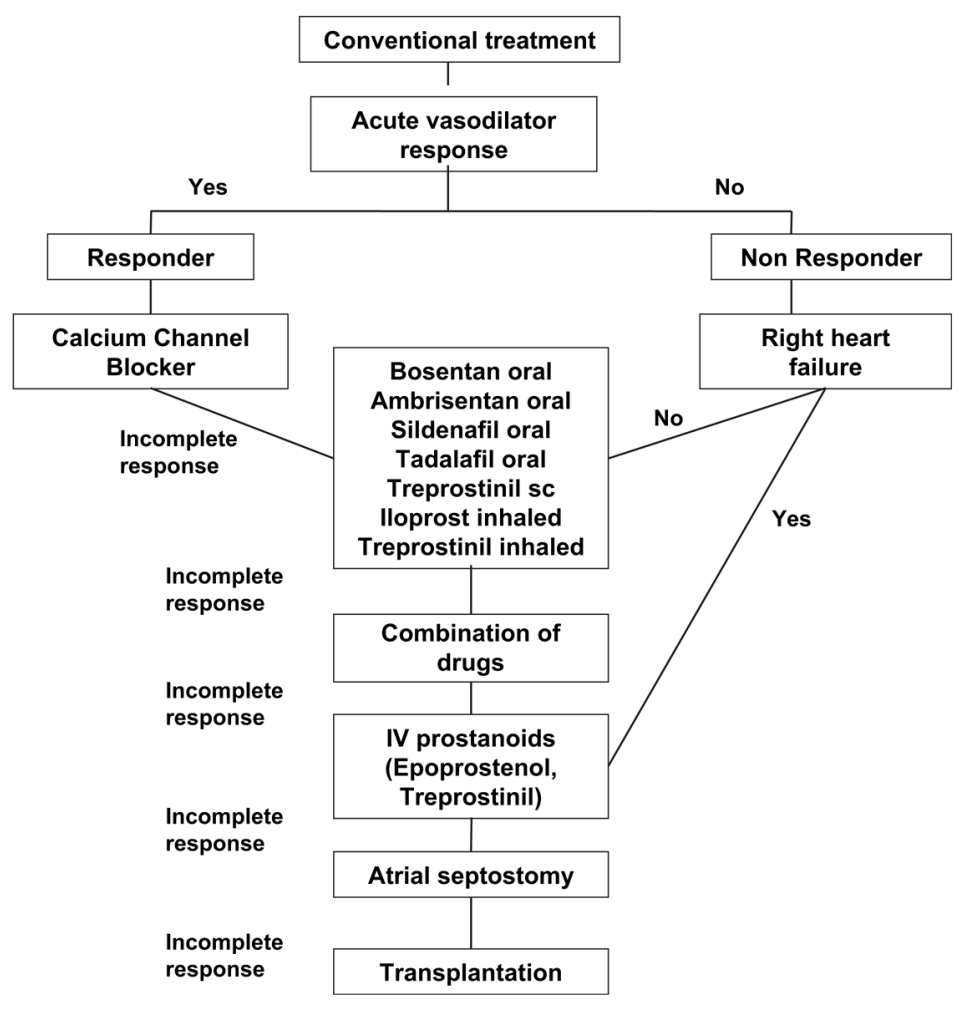

Figure.

Treatment algorithm in children with severe pulmonary arterial hypertension. 